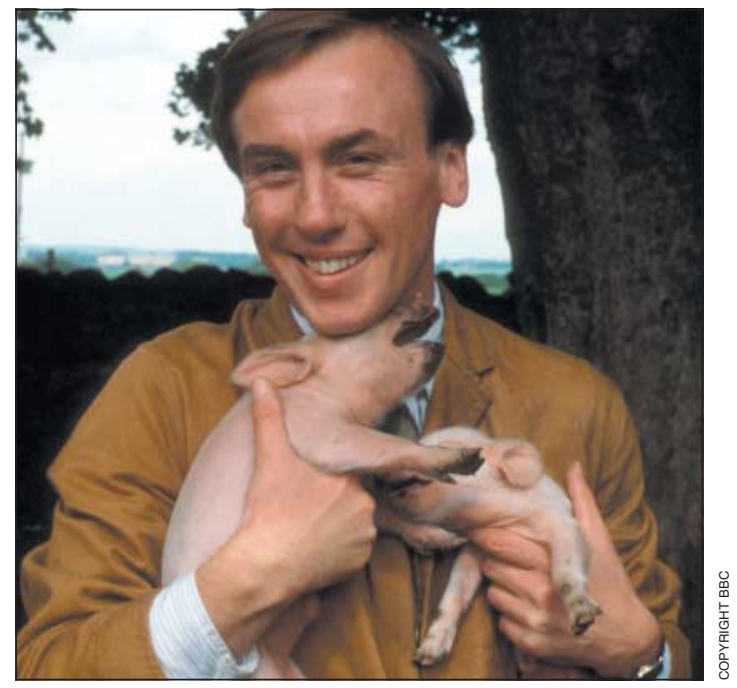

James Herriot-the popular vet from the television series All Creatures Great and Small

genome sequences between dogs, horses, cats, and humans is well advanced, ${ }^{67}$ with progress also in pigs, cattle, and sheep. Dogs combine exceptional phenotypic diversity, exemplified by breed differences in size and lifespan, with a relatively uniform genotype. Among some 370 canine genetic disorders, about half have exact human analogues. ${ }^{8}$ They generally resemble the human disease more closely than do rodent models, reflecting closer evolutionary kinship and DNA sequence identity. ${ }^{9}$ The National Human Genome Research Institute regards the canine genome as a key research priority. Molecular genetics adds new dimensions to comparative studiesidentification of novel disease genes, new disease models, new molecular targets for drugs, evaluation of gene therapy, and elucidation of genotypic variation in therapeutic responses.

Comparative medicine emerged from the realisation that humans and animals shared similar cellular structures and mechanisms and faced challenges from similar microorganisms. But disease models were just that; resemblances between diseases. Now molecular science can show identical receptors, mediators, and genes. This should not surprise us, unless we are creationists; we share a rich evolutionary legacy of genes, many involved in diseases. Comparative medicine is no longer the study of mere similarities but of the same disease in different species. We need parallel development of comparative clinical studies and research in molecular genetics. The Comparative Clinical Science Panel should provide the necessary strategic coherence to yield knowledge and reduce suffering, unfettered by species. ${ }^{10}$ In 1988 Stewart Cameron wrote: "Too little attention has been paid to comparison of human and spontaneous animal disease, either by veterinarians or physicians, and it is to be hoped that greater exchange of information can be organised in future." ${ }^{11}$ With the development of the Comparative Clinical Science Panel, this hope may now be fulfilled.

Bob Michell professor of comparative medicine

Barts and The London School of Medicine and Dentistry, John Vane Science Centre, London EC1M 6BQ

(bobmichell@hotmail.com)

Competing interests: None declared.

1 Coleman RA. Of mouse and man-what is the value of the mouse in predicting gene expression in humans? Drug Discov Today 2003;8:233-5.

Galibert F, Wilton AN, Chuat J. The canine model in medical genetics. In: Ruvinsky A, Sampson J, eds. The genetics of the dog. Wallingford: CABI, 2001:503-20.

3 Ostrander EA, Krugylack L. Unleashing the canine genome. Genome Research 2000;10:1271-4

4 Argyle DJ, Nasir L. Pathophysiology of cell regulation, cell death and cancer. In: Dunlop RH, Malbert C-H, eds. Veterinary pathophysiology. Oxford: Blackwell, 2004:25-78.

5 Michell AR. The clinical biology of sodium. Oxford: Pergamon, 1995:105-54 Breen M, Switonski M, Binns MM. Cytogenetics and physical maps. In: Ruvinsky A, Sampson J, eds. The genetics of the dog. Wallingford: CABI, 2001:299-328.

7 Chowdhary BP, Raudsepp T, Kata SR, Goh G, Millon LV, Allan V, et al. The first-generation whole-genome radiation hybrid map in the horse identifies conserved segments in human and mouse genomes. Genome identifies conserved
Res 2003;13:742-51.

8 Nicholas A. Genetics of morphological traits and inherited diseases. In: Ruvinsky A, Sampson J, eds. The genetics of the dog. Wallingford: CABI, 2001:87-116.

9 Van De Sluis B, Rothuizen J, Pearsen PI, Van Oost BA, Wijmenga C. Identification of a new copper metabolism gene by positional cloning in a purebred dog population. Hum Mol Genet 2002;11:165-73.

10 Michell AR. Comparative clinical science: the medicine of the future Veterinary Journal 2005;170;153-62.

11 Cameron JS. Glomerular disease in humans; comparative aspects. In: Michell AR, ed. Renal disease in dogs and cats; comparative and clinical aspects. Oxford: Blackwell Scientific, 1988:99-104.

\title{
Human health and nature conservation
}

\section{Ecotherapy could be beneficial, but we need more robust evidence}

$\mathrm{W}$ e call animals in their natural habitat wild, implying danger. Research that focuses on risk can foster a fearful attitude towards nature, disabling society's capacity for choice. ${ }^{1}$ These fearful views from contemporary anthropology contrast sharply with the biological, evolutionary, and ecological view of the influential American zoologist Edward Wilson. Wilson coined the concept of biophilia: "The connection that human beings subconsciously seek and need with the rest of life."' This view, emphasising connection with nature, builds on behavioural observations by Konrad Lorenz, a Nobel prize
The therapeutic implication of biophilia is ecotherapy: restoring health through contact with nature. ${ }^{4}$ British author Gregory Bateson's theoretical framework for improving health through conserving nature incorporated a "sense of unity of biosphere and humanity" that engenders connection, restoration, and respect for self and planet. ${ }^{5}$

The Society for Companion Animal Studies promotes pets for health, a topic discussed by McNicholas and colleagues in this issue. ${ }^{6}$ But extra benefits may come from the naturalness factor arising from connection with wildlife. Use of wildlife in some therapies is reported to improve quality of life. ${ }^{7}$ Smaller 


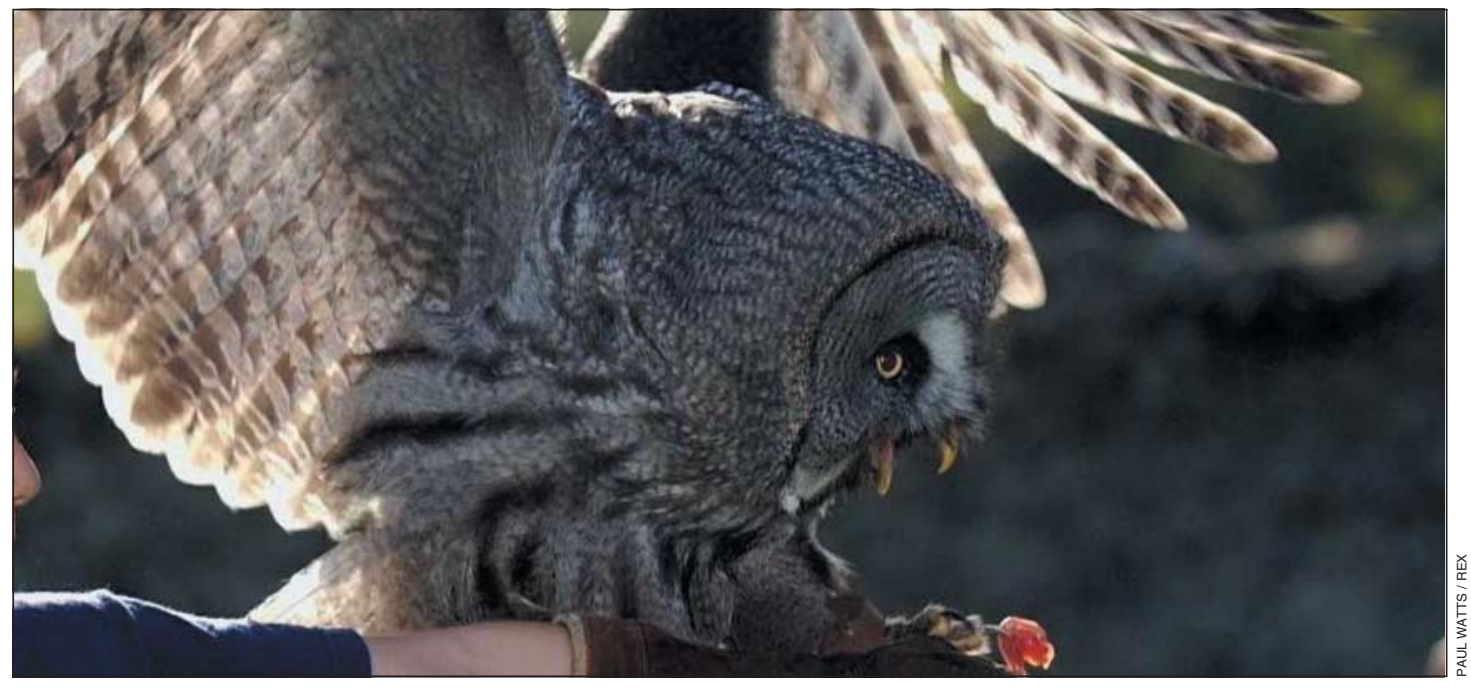

Smaller animals such as owls have been used in therapies for children

animals (for example, squirrels, owls, and raccoons) have been used successfully in therapies for children with emotional and behavioural problems. ${ }^{8}$

Most therapies involve participation in conservation projects. Some projects focus on large species in challenging environments, such as nature therapist Ronen Berger's work with endangered wolves and birds of prey in the Israeli wilderness ${ }^{9}$ and Antonioli and Reveley's use of dolphins in the Caribbean. ${ }^{10}$ Projects in the United Kingdom, such as the Essex Growing Together community initiative, conserve species varying from badgers to rare moths. Many projects address mental health needs and usually involve small groups of patients under supervision. ${ }^{11}$ Wildlife gardens can flourish in small spaces close to human habitation, like Addenbrooke's Hospital's Jubilee garden developed by a stroke patient during rehabilitation.

People who take part in conservation projects report subjective health benefits, ascribed to being outdoors and to feeling part of a greater system connecting beyond the individual. Such projects can help overcome social isolation among people with disabilities through embracement, ${ }^{12}$ develop skills, and improve employment prospects as well as provide the known benefits associated with exercise. One volunteer in the Meanwhile Wildlife Garden project, run by the mental health charity Mind to conserve a small wildlife habitat in inner London, described his experience: "Initially it was something that I would do as I recovered from my illness, but now it has become the main focus of my energies." ${ }^{13}$ Conservation led him to a recognised qualification and paid employment in urban gardening.

In our observations of ecotherapy projects we have noted few risks to health, and any injuries have been minor-for example, a superficial animal bite. Indeed, established projects were excellent examples of risk management for potential hazards (such as those related to equipment or terrain).

Although initial scoping research has been promising, the UK needs robust evidence such as health impact assessments of wildlife projects to determine their objective therapeutic value. Public health, clinical, and educational services need to act to provide this evidence, allowing research and practice to grow together. English Nature has advocated a national strategy to encourage people to reconnect with nature and benefit from proximity to wildlife. ${ }^{14}$ Partnerships between healthcare providers and nature organisations to share and exchange expertise could create new policies that recognise the interdependence between healthy people and healthy ecosystems.

Ambra Burls senior lecturer in mental health

(a.burls@apu.ac.uk)

\section{Woody Caan professor of public health}

Institute of Health and Social Care, Anglia Ruskin University, Chelmsford, Essex CM1 1SQ

Competing interests: $\mathrm{AB}$ is participating in a collaborative, multicentre educational development for ecotherapy.

1 Lanternari V. Ecoantropologia. Dallingerenza ecologica alla suolta eticoculturale Bari: Dedalo, 2000:440.

Wilson EO. Biophilia. Cambridge, MA: Harvard University Press, 1984.

Lorenz KZ. Les prix Nobel. Stockholm: Karolinska Institute, 1973.

4 Cohen MJ. Counselling and nature: the greening of psychotherapy Interpsych Newsletter 1995;2(4). http://userpage.fu-berlin.de/ expert/ psychnews/ix.htm (accessed 21 Nov 2005).

5 Bateson G. Mind and nature. A necessary unity. Toronto: Bantam, 1979.

6 McNicholas J, Gilbey A, Rennie A, Ahmedzai S, Dono J-A, Ormerod E. Pet ownership and human health: a brief review of evidence and issues. BMJ 2005;331:1252-5.

7 Maller C, Townsend M, Brown P, St Leger L. Healthy parks healthy people. The health benefits of contact with nature in a park context. Melbourne: Faculty of Health and Behavioural Sciences, Deakin University, 2002.

8 Nebbe L. Animal-assisted activities/therapy as an animal and human welfare project. Humane Innovations and Alternatives 1994. www.psyeta.org/ hia/vol8/nebbe.html (accessed 17 Nov 2005).

9 Berger R. In the footsteps of nature. Horizons 2003;22:27-32.

10 Antonioli C, Reveley MA. Randomised controlled trial of animal facilitated therapy with dolphins in the treatment of depression. BMJ 2005;331:1231-4

11 Burls A New landscapes for mental health. Mental Health Rev 2005;10:26-9.

12 Burls A, Caan A. Social exclusion and embracement: a helpful concept? Primary Health Care Res Dev 2004;5:191-2.

13 Kensington and Chelsea MIND. Meanwhile wildlife gardens. London: MIND, 2003:14-5.

14 English Nature. Nature and psychological well-being. London: English Nature, 2003. (Research report 533.) 